Yüzüncü Yil Üniversitesi
Tarim Bilimleri Dergisi

Araştırma Makalesi (Research Article)

Pretreatment Effect on Amelioration of Seed Germination of Zollinger's Indigo (Indigofera zollingeriana Miq.) $^{* *}$

\author{
Siti MAESAROH ${ }^{1 *}$, Nurdan ŞAHİN DEMIRBAĞ $\breve{G}^{2}$ \\ ${ }^{1,2}$ Departement of Field Crops, Faculty of Agriculture, Ankara University, Ankara, Turkey \\ ${ }^{1}$ https://orcid.org/0000-0003-1024-284X ${ }^{2}$ https://orcid.org/0000-0002-8345-1768 \\ *Corresponding Author e-posta: maesaroh@ankara.edu.tr
}

\section{Article Info \\ Keywords \\ Dormancy, Immersion, \\ Legume, \\ Scarification, \\ Soaking.}

Received: 23.10.2019

Accepted: 18.01.2020

Online Published 31.03.2020

DOI: 10.29133/yyutbd.637005

\begin{abstract}
Indigofera zollingeriana is one of Indigofera species distributed in Indonesia and known as forage crop. Seed is an important factor which influences cultivation of $I$. zollingeriana due to low seed germination. The objective of the research was to determine the effect of different pre-treatment as chemical scarification (98\% of $\mathrm{H}_{2} \mathrm{SO}_{4}, 0.3 \%$ of $\mathrm{KNO}_{3}$, glycerine $\left(\mathrm{C}_{3} \mathrm{H}_{8} \mathrm{O}_{3}\right)$ at $70^{\circ} \mathrm{C}$ ), hot water at $70^{\circ} \mathrm{C}$ with different duration of immersion or soaking and mechanical scarification using sand paper on I. zollingeriana's seed germination. Pretreatment had significant differences and improved germination percentage, germination speed index and shoot length. The positive correlation was noted between germination percentage and germination speed index.
\end{abstract}

\title{
Indigofera zollingeriana'nın Tohum Çimlenmesinde Ön İşlem Etkisinin İyileştirilmesi
}

Makale Bilgileri

Geliş: 23.10.2019

Kabul: 18.01.2020

Online Yayınlanma 31.03.2020

DOI: $10.29133 /$ yyutbd.637005

\section{Anahtar kelimeler}

Dormansi,

Daldirma,

Baklagil,

Aşındırma,

Islatma.
Öz: Indigofera zollingeriana, Endonezya'da dağılış gösteren ve yem bitkisi olarak bilinen Indigofera türlerinden biridir. Endonezya'da I. zollingeriana'nın yetiştiriciliğini etkileyen en önemli faktör, tohumundaki düşük çimlenme oranıdır. Bu çalışmada, I. zollingeriana tohumlarında, farklı sürelerde kimyasal uygulamalarının (\%98'lik $\mathrm{H}_{2} \mathrm{SO}_{4}, \% 0.3$ 'lük $\mathrm{KNO}_{3}, 60^{\circ} \mathrm{C}$ 'lik $\mathrm{C}_{3} \mathrm{H}_{8} \mathrm{O}_{3}$ çözelti), $70^{\circ} \mathrm{C}^{\prime}$ lık sıcak su ve zımpara kâğıdı ile tohumu mekanik olarak aşındırma şeklinde yapılan çimlendirme ön uygulamalarının etkilerinin belirlenmesi amaçlanmıştır. Araştırma sonuçlarına göre; ön uygulamalarda çimlenme yüzdesi, çimlenme hızı endeksi ve sürgün uzunluğu bakımından önemli farkl11ıklar gözlenmiş olup, incelenen parametrelerde aynı zamanda artış da tespit edilmiştir. Çimlenme yüzdesi ile çimlenme hızı endeksi arasında pozitif korelasyon saptanmıştır.

\footnotetext{
${ }^{* *}$ This reasearch is a part of master thesis conducted by Siti MAESAROH.
}

\section{Introduction}

Indiofera zollingeriana is one of the widely used forage plant species used in Indonesia due to high quality forage production and adaptability to drought stress under tropic conditions (Abdullah, 2010; Herdiawan and Sutedi, 2012). The plant has protein rich leaves with low tannin, lignin and cellulose contents, utilisable fibre (NDF and ADF) and high dry matter digestibility (Abdullah, 2010). 
Palupi (2015) reported that top leaf meal of $I$. zollingeriana contain $28.98 \%$ crude protein, $3.30 \%$ crude fat, $8.49 \%$ crude fiber, $0.52 \%$ calcium and $0.34 \%$ phosphorus. Dianita (2012) noted interaction of arbuscular mycorrhizal fungi (FMA) had important role for transferring phosphorous and nitrogen in Indigofera.

Low seed viability influence plant growth and affect plant production and multiplication. Most $(<85 \%)$ of the legumes have hard or impermeable seed coat (Guppy, 1912). Harrington (1916) observed that most of this is physical dormancy caused by hard seed coat that results in slow germination and development of plants. Mechanical or chemical scarification can break seed coat where metabolic inhibitor of seed is located (Copeland and McDonald, 1999). The seed condition (quality) is one of particular importance to plant cultivation in agriculture sector that rely on seed germination.

Abdullah (2014) has further reported that seed storage over 4 weeks on I. zollingeriana could result in decreases seed germination by $24 \%$. Abdullah et al. (2016) has observed that long storage period affected hypocotyl length of the germinated seeds and increased mold contamination. The researcher conceived that these factors lead to poor germination of I. zollingeriana.

The study aimed to factors affecting seed dormancy and improves seed germination of $I$. zollingeriana.

\section{Material and Methods}

The seeds were collected from Prof. Dr. Luki Abdullah of the Department of Nutrition Science and Feed Technology, Bogor Agricultural University, Indonesia. Randomly selected healthy 3 months old yellow-brown coloured uniform seeds were selected for the experiment. Hundred (100) seed weight was measured (ISTA, 1966) and then moisture content of the seeds was determined using International Rules for Seed Testing (ISTA, 2003).

\subsection{Pre-treatment and germination on I. zollingeriana seed}

Eighteen pre-treatment with a control (untreated seed) were conducted on 75 seeds each of $I$. zollingeriana. The seeds were scarified using $98 \%$ of $\mathrm{H}_{2} \mathrm{SO}_{4}$ for $5,10,15$ and $20 \mathrm{~min}$. The seeds were also scarified with $0.3 \% \mathrm{KNO}_{3}$ (Potassium nitrate) for 12, 24, 36 and $48 \mathrm{~h}$ and $\mathrm{C}_{3} \mathrm{H}_{8} \mathrm{O}_{3}$ (glycerine) at $60^{\circ} \mathrm{C}$ for 30, 60, 90 and 120 min. All chemically scarified seeds were rinsed in running tap water for 510 min to remove traces of the treated chemicals until they were safe to culture for germination. Similarly, the seeds were mechanically scarified with sand paper using two and four scratches and treated with hot water at $70^{\circ} \mathrm{C}$ for $30,60,90$ and $120 \mathrm{~min}$.

Each of twenty five treated seeds was placed in Petri dishes lined with filter papers containing $10 \mathrm{ml}$ of distilled water. Then, the seeds were cultured in growth cabinet at $24 \pm 1^{\circ} \mathrm{C}$ under dark conditions.

\subsection{Measurement}

Germination was observed daily until 14 days of germination (ISTA, 2007) and the seeds with $2 \mathrm{~mm}$ radicle length were counted as germinated. Growth rate was measured by taking length of 5 randomly selected seedlings. The germination parameters included germination percentage following Bewley and Black (1994).

$$
\mathrm{GP}(\%)=\frac{\sum \mathrm{ni}}{\mathrm{N}} \times 100 \%
$$

Where, GP (\%) is the germination percentage, " $\mathrm{n}$ " is the number of normal germinated seeds at " $\mathrm{i}$ " day, and $\mathrm{N}$ is the total number of incubated seeds per test.

Speed germination was calculated by Germination Speed Index (GI), $\mathrm{N}$ is the number of normal germinated seeds at day "i" and D is day of count at day "i" $\mathrm{n}$ following Maguire (1962) and Gupta (1993) on the last day of count (7 days).

$$
\mathrm{GI}=\sum_{\mathrm{i}=1}^{\mathrm{n}} \frac{\mathrm{Ni}}{\mathrm{Di}}
$$




\subsection{Statistical analysis}

The experiment was designed in a Completely Randomized Design (CRD) with 3 replications. The collected data expressed in percentage were Arcsine transformed (Steel and Torrie, 1980) before analysis of variance. The difference among means was compared by using Duncan's Multiple Range Test (DMRT). Correlation among germination parameters were analyzed using Pearson Correlation coefficient.

\section{Results and Discussion}

\subsection{Seed weight and moisture content}

Hundred seed weight was measured as $0.67 \mathrm{~g}$ at seed moisture content of $6.38 \%$ and this moisture content was noted for safe storage period on orthodox seeds in agreement with Roberts (1973). These seeds were subjected to seed germination experiments. I. zollingeriana which has hard seed coat can protect embryo during storage. Advantages of hard and thick seed coats in legume orthodox seeds are preservation of low level of metabolism by prohibiting moisture and oxygen during storage and embryo protection against mechanical damage during collection and storage (Bonner, 2008). Copeland and McDonald (1999) observed that sensitivity of large-seeded legumes and damage could be reduced $>15 \%$ seed moisture. They also noted that the threshold moisture content for smallseeded legume is 8 to $10 \%$.

\subsection{Seed Germination}

The result show that there was a significant $(\mathrm{p}<0.05)$ different effect of pre-treatments on seed germination of I. zollingeriana (Table 1). The range of germination percentage was 4-78.67\% after 14 days. Seed treated by sandpaper, sulphuric acid and potassium nitrate showed improvement in seed germination. The highest seed germination percentage of $78.67 \%$ and $76 \%$ were obtained on sandpaper scarified seeds after 2 and 4 scratches compared to control group and other pre-treatments. The effectiveness of sandpaper scarification was similar to Hassen et al. (2004) who noted improvement of seed germination by sandpaper scarification in 6 accessions of Indigofera ( $I$. cryptantha, I. brevicalyx, I. arrecta, I. spicata, I. trita and I. spicata). In other studies Uzun and Aydin (2004) and Okunlola et al. (2011) emphasized the effectiveness of sandpaper scarification that showed high germination percentage on forage legumes as Medicago and Trifolium and African locust bean.

Sandpaper scarification by hand promoted the reduction on hard layer seed coats of $I$. zollingeriana. Similarly, mechanical scarification using sandpaper overcome physical dormancy due to hardness of seed coat by removing a thick palisade layer of macrosclereid cells characteristic of leguminosae related to water impermeability (Yildiztugay and Kucukoduk, 2012; Smykal et al., 2014; Chaves et al., 2017). However, some germinated seeds of I. zollingeriana appeared with root damage marked by black root tip. It is assumed that characteristics phenolic compounds in root cells got oxidized on contact with air and resulted in damage of the root tips in agreement with Kefeli et al., 2003, He et al., 2009. Therefore, care is needed during scratching of seeds to avoid damage to radicles. Careless scratching could result in damage to seeds or seed radicle micropylar regions fully or partially in agreement with Schmidth (2002) and Chaves et al. (2017).

The second highest germination percentage was in range $38.67-52 \%$ on seeds scarified with sulphuric acid. The effectiveness of sulphuric acid cracking and softening seed coats is in agreement with Missanjo et al. (2013) and Olatunji et al. (2013) who studied effect of pre-treatments on legumes seed germination. The seed germination after sulphuric acid scarification was lower compared to mechanical scarification with sandpaper. This could be due to long duration of immersion or high concentration of sulphuric acid that leads to embryo damage of a large quantity of seeds depending on resistance of inner integument. Missanjo et al. (2013) and Asaadi et al. (2015) also confirmed sulphuric acid was effective to improve germination percentage but they noted there was injury on embryo structure.

Three of $\mathrm{KNO}_{3}$ durations treatments had germination percentage in range of 14.67-25.33\%. These results are not in agreement with previous studies where potassium nitrate has been reported to 
break seed dormancy and promote seed germination (Gashi et al., 2012) on Romonda nathaliae. Yucel (2000) reported potassium nitrate was specified as growth-regulating substance in Salvia species. It is conceived that the difference in germination percentage could be due to poor compatibility of the seeds, long duration of treatment period or concentration of potassium nitrate that have not significant effects on germination percentage of I. zollingeriana. Sarihan et al. (2005) and Gashi et al. (2012) noted that the appropriate concentration of $\mathrm{KNO}_{3}$ improved germination seed on Plantago lanceolata L. and Romando nathaliae. Atalay et al. (2011) reported that $<24$ h treatment with $0.5 \%$ potassium nitrate had negative effects on seed germinability and caused decreased seed germination of Triticum aestivum.

The hot water treatment with water at $70^{\circ} \mathrm{C}$ was not effective to improve germination of $I$. zollingeriana. The seed germination ranged $4-13.33 \%$. Contrarily, Hassen et al. (2004) reported the effectiveness of $93^{\circ} \mathrm{C}$ of boiled water on germination of I. arrecta, I. vohemarensis and I. trita that showed improved germination percentage without remarkable risk on seed mortality. Although long duration of soaking of $I$. zollngeriana softened hard seed coats and also increased number of dead seeds due to embryo or cotyledon damage showed by extremely soft seed with fungal growth in agreement with McIvor and Gardener (1987), McDonnell et al. (2012) and Ghadir et al. (2012). These researchers confirmed that water temperature and soaking periods play an important role in seed germination.

Treatment with glycerine at $60^{\circ} \mathrm{C}$ resulted in seed germination range of $5.33-12 \%$ that was lower than before mentioned seed germinations. It could be due to by low temperature of glycerine that did not induce seed coat cracking. The boiling point of pure glycerine is $290^{\circ} \mathrm{C}$ at $760 \mathrm{~mm}$ (atmospheric pressure) (Anonymous, 1990). Wycherley (1960) and Schmidt (1961) emphasized use of warm treatment as glycerine was more effective to accelerate seed germination especially on some legumes. Moreover, all pre-treatment works by removing inhibitors like hard seed coat induced water and gas permeability was not much effective in this case and poorly promoted seed germination in accordance with Copeland and McDonald (1999).

There was significant difference $(\mathrm{p}<0.05)$ on germination speed showed by germination speed index value (Table 1). The result showed that sandpaper scarification, sulphuric acid scarification and potassium nitrate immersion improved germination speed with 4.49-24.36 germination index indicated seed quickly germinate and physiological quality. Seeds treated by specific duration on some glycerine and hot water had higher germination index than control group but the difference between the two was no significant. The results are similar to Rusdy (2015) who reported that sulphuric acid immersion and sand paper scarification increased germination speed on legume Centrocema pubescens. Germination index was positively correlated to germination percentage with $r=0.964$ (Table 2). The results are in agreement with Santos (2010). Doni et al. (2014) reported that hydro treatment could increase seed germination percentage and germination speed of Oryza sativa. Gairola et al. (2011) and Abiri et al. (2016) reported that there was a significant positive correlation between germination percentage and germination speed on legume Jatropha curcas and six indica rice cultivars. They also reported that vigor of stored seed declines before seeds lose their ability to germinate (Delouche, 1965; Shaban, 2013).

The maximum root length was noted on the seeds germinated after $0.3 \% \mathrm{KNO}_{3}$ treatment for $48 \mathrm{~h}$ (Table 1). It is similar to Taheri et al. (2014) who reported the effectiveness of $\mathrm{KNO}_{3}$ to improve root length of Punica granatum due to faster emergence of roots and shoots. There were no significant differences among some pre-treated seeds in agreement with Karaguzel et al. (2004) and Gunes et al. (2013), who noted pre-treatment had no significant effect on roots of Lupinus varius and Ceratonia siliqua root length. Potassium has substantial effect on water relation (osmotic adjustment and turgor regulation) stomatal movement, enzyme activation, photosynthesis, protein synthesis in plants (Marschner, 1995). Bhandal and Malik (1988) reported that more than 50 enzymes are activated by $\mathrm{K}^{+}$. Thus, optimum levels $\mathrm{K}^{+}$can improve various enzymatic processes in the cytoplasm. Therefore, it was suggested that optimum concentration of $\mathrm{K}^{+}$at the cellular level might have acted as contributory factor for root growth and had reduced salt induced oxidative stress with lesser cell damage. This might had resulted in improved root length on the germinating seedlings in agreement with Shen et al. (2000). 
Table 1. Effect of Pre-Treament on Seed Germination and Seedling Growth of I. zollingeriana

\begin{tabular}{|c|c|c|c|c|c|}
\hline & Pre-Treatment & $\begin{array}{c}\text { Germination } \\
\text { Percentage (\%) }\end{array}$ & $\begin{array}{l}\text { Germination } \\
\text { Speed Index }\end{array}$ & $\begin{array}{l}\text { Root Length } \\
\quad(\mathrm{cm})\end{array}$ & $\begin{array}{l}\text { Shoot } \\
\text { Length } \\
(\mathrm{cm})\end{array}$ \\
\hline T0 & Control & $13.33_{\text {cde }}$ & $1.76^{\text {efgh }}$ & $1.9_{\text {abcde }}$ & $1.5_{\mathrm{f}}$ \\
\hline $\mathrm{T} 11$ & $95-98 \% \mathrm{H}_{2} \mathrm{SO}_{4} 5 \mathrm{~min}$ & $52.00_{\mathrm{b}}$ & $12.42^{\mathrm{b}}$ & $1.9_{\text {abcde }}$ & $3.5_{\mathrm{cdef}}$ \\
\hline $\mathrm{T} 12$ & $95-98 \% \mathrm{H}_{2} \mathrm{SO}_{4} 10 \mathrm{~min}$ & $38.67 b$ & $9.47^{\mathrm{bc}}$ & $1.8_{\text {abcde }}$ & 3.7 bcde \\
\hline $\mathrm{T} 13$ & $95-98 \% \mathrm{H}_{2} \mathrm{SO}_{4} 15 \mathrm{~min}$ & $45.33_{b}$ & $9.74^{\mathrm{bc}}$ & $1.8_{\text {abcde }}$ & $3.4_{\mathrm{de}}$ \\
\hline $\mathrm{T} 14$ & $95-98 \% \mathrm{H}_{2} \mathrm{SO}_{4} 20 \mathrm{~min}$ & $40.00_{\mathrm{b}}$ & $8.31^{\mathrm{bc}}$ & $1.6_{\mathrm{be}}$ & $3.4_{\mathrm{de}}$ \\
\hline $\mathrm{T} 21$ & $0.3 \% \mathrm{KNO}_{3} 12 \mathrm{~h}$ & $14.67_{\text {cde }}$ & $4.49^{\text {de }}$ & $1.8_{\text {abcde }}$ & $5.0_{\mathrm{abcd}}$ \\
\hline $\mathrm{T} 22$ & $0.3 \% \mathrm{KNO}_{3} 24 \mathrm{~h}$ & $25.33_{c}$ & $10.33^{\mathrm{b}}$ & $2.1_{\mathrm{abcd}}$ & $5.2_{\mathrm{abc}}$ \\
\hline $\mathrm{T} 23$ & $0.3 \% \mathrm{KNO}_{3} 36 \mathrm{~h}$ & $22.67_{\text {cd }}$ & $8.20^{\mathrm{bc}}$ & $1.9_{\text {abcde }}$ & $5.4_{\mathrm{ab}}$ \\
\hline $\mathrm{T} 24$ & $0.3 \% \mathrm{KNO}_{3} 48 \mathrm{~h}$ & $13.33_{\text {cde }}$ & $5.33^{\mathrm{cd}}$ & 2.6a & $5.5 \mathrm{ab}$ \\
\hline T31 & $60^{\circ} \mathrm{C} \mathrm{C}_{3} \mathrm{H}_{8} \mathrm{O}_{3} 30 \mathrm{~min}$ & $12.00_{\mathrm{def}}$ & $3.65^{\mathrm{def}}$ & $2.5_{\mathrm{ab}}$ & 4.4 abcde \\
\hline Т32 & $60^{\circ} \mathrm{C} \mathrm{C}_{3} \mathrm{H}_{8} \mathrm{O}_{3} 60 \mathrm{~min}$ & $8.00_{\mathrm{ef}}$ & $1.84^{\mathrm{efg}}$ & $1.7_{\text {abcde }}$ & 4.9 abcd \\
\hline Т33 & $60^{\circ} \mathrm{C} \mathrm{C}_{3} \mathrm{H}_{8} \mathrm{O}_{3} 90 \mathrm{~min}$ & $10.67_{\text {ef }}$ & $1.88^{\mathrm{efg}}$ & $1.4_{\mathrm{de}}$ & $3.1_{\mathrm{ef}}$ \\
\hline T34 & $60^{\circ} \mathrm{C} \mathrm{C}_{3} \mathrm{H}_{8} \mathrm{O}_{3} 120 \mathrm{~min}$ & $5.33_{\mathrm{ef}}$ & $1.12^{\mathrm{fgh}}$ & $2.1_{\mathrm{abc}}$ & $3.1_{\text {ef }}$ \\
\hline T41 & $70^{\circ} \mathrm{C}$ hot water $30 \mathrm{~min}$ & $4.00_{\mathrm{f}}$ & $0.18^{\mathrm{h}}$ & $1.6_{\text {bcde }}$ & $3.1_{\text {ef }}$ \\
\hline T42 & $70^{\circ} \mathrm{C}$ hot water $60 \mathrm{~min}$ & $9.33_{\mathrm{ef}}$ & $2.48^{\text {defg }}$ & $2.4_{a b c}$ & $5.6 a^{* * *}$ \\
\hline T43 & $70^{\circ} \mathrm{C}$ hot water $90 \mathrm{~min}$ & $13.33_{\text {cde }}$ & $1.27^{\text {fgh }}$ & $1.8_{\text {abcde }}$ & 4.1 $1_{\mathrm{abcde}}$ \\
\hline T44 & $70^{\circ} \mathrm{C}$ hot water $120 \mathrm{~min}$ & $9.33_{\mathrm{ef}}$ & $0.92^{\mathrm{gh}}$ & $1.6_{\mathrm{bcde}}$ & $3.4_{\mathrm{de}}$ \\
\hline T51 & Sandpaper 2 scratch & 78.67a & $22.31^{\mathrm{a}}$ & $1.1_{\mathrm{e}}$ & $3.3_{\mathrm{de}}$ \\
\hline T52 & Sandpaper 4 scratch & $76.00 \mathrm{a}$ & $24.36^{a}$ & $1.6_{\text {bcde }}$ & $3.8_{\text {bcde }}$ \\
\hline
\end{tabular}

Pre-treatment has significant $(\mathrm{P}<0.05)$ different effect in germinated seed of I. zollingeriana that increased shoot length more than control group in range 3.3-5.6 cm after 14 days. It might have been caused by increasing quick seed germinated lead to early photosynthesis in agreement with Mabhaudhi (2009). There were no significant correlation between germination percentage and both of root length and shoot length (Table 2).

Table 2. Pearson correlation coefficient matrix between some germination and vigour test parameters on I. zollingeriana seed.

\begin{tabular}{cccc}
\hline Correlation & Germination Index & Shoot Length & Root Length \\
\hline \multirow{2}{*}{ Germination Percentage } & 0.964 & -0.169 & -0.452 \\
& $0.000^{*}$ & $0.488^{\text {ns }}$ & $0.052^{\text {ns }}$ \\
\hline \multirow{2}{*}{ Germination Speed Index } & & -0.004 & -0.35 \\
& & $0.988^{\text {ns }}$ & $0.142^{\text {ns }}$ \\
\hline
\end{tabular}

* ns : significant and non-significant at $5 \%$ probability

\section{Conclusion}

Different pre-treatment had different effects and promoted germination on I. zollingeriana seed showed by the same germination parameters. Scarification by sandpaper could be an alternative to break hard seed coat of I. zollingeriana in laboratory scale. Appropriate pre-treatment can improve germination parameters. Therefore, the easy, low cost and quick pre-treatment's data obtained from laboratory study can be a recommended for faster ex situ germination and nursery establishment.

\section{Acknowledgements}

The authors are grateful to Prof. Luki Abdullah, Bogor Agricultural University, for help in give of seeds. 


\section{References}

Abdullah, L. (2010). Herbage production and quality of shrub Indigofera treated by different concentration of foliar fertiliser. Media Peternakan, 33(3), 169-175.

Abdullah, L. (2014). Prospektif agronomi dan ekofisiologi Indigofera zollingeriana sebagai tanaman penghasil hijauan pakan berkualitas tinggi. Pastura, 3(2), 79-83. (in Indonesian language)

Abdullah, L., Girsang, R. C., Putra, N. P., Wiryawan, K. G. \& Permana, I. G. (2016). Viabilitas, Intensitas Kontaminasi Jamur dan Tinggi Hipokotil sebagai Respon terhadap Modifikasi Atmosfer dengan Injeksi $\mathrm{CO}_{2}$ Selama Penyimpanan Benih Indigofera zollingeriana. In: L. Abdullah, D. A. Astuti, Suharlina (Eds.), Bunga Rampai Hasil Riset dan Pengembangan Indigofera zollingeriana (pp. 6-13). Bogor, Indonesia: IPB Press. [in Indonesian language]

Abiri, R., Shaharuddin, N. A., Maziah, M., Yusof, Z. N. B., Atabaki, N., Sahebi, M. \& Azizi, P. (2016). Quantitative assessment of indica rice germination to hydropriming, hormonal priming and polyethylene glycol priming. Chilean Journal of Agriculture Research, 76(4), 392-400.

Anonymous. (1990). Glycerine: an Overview. The Soap and Detergent Assosiation. New York.

Asaadi, A. M., Heshmati, G. \& Dadkhah, A. (2015). Effects of different treatments to stimulate seed germination of Salsola arbusculiformis Drob. Ecopersia, 3(3), 1077-1088.

Atalay, E., Yetim, E., Soylu, S., Sade, B. \& Yorgancilar, M. (2011). Farkl priming uygulamalarınin ekmeklik buğday çeşitlerinde çimlenmenin başlangıç dönemdeki etkinliği. Türkiye IV. Tohumculuk Kongresi, Samsun, Turkiye, 535-539.

Bhandal, I. S. \& Malik, C. P. (1988). Potassium estimation, uptake, and its role in the physiology and metabolism of flowering plants. International Review of Cytology, 110, 205-254.

Bewley, J. D. \& Black, M. (1994). Seeds: Physiology of Development and Germination. New York, USA: Plenum Press, 445.

Bonner, F. T. (2008). Storage of Seed. In: F. T. Bonner, R. P. Karrfalt \& R. G. Nisley (Eds.), The Woody Plant Seed Manual (pp. 85-96). New York, USA: United States Departement of Agriculture.

Chaves, I. S., Silva, N. C. Q. \& Ribeiro, D. M. (2017). Effect of the seed coat on dormancy and germination in Stylosanthes humilis H. B. K. seeds. Journal of Seed Science, 39(2), 114-122.

Copeland, L. O. \& McDonald, M. B. (1999). Seed Science and Technology (3rd Ed.). New York, USA: Kluwer Academic Publishers.

Delouche, J. C. (1965). An accelerated aging technique for predicting relative storabiltiy of crimson clover and tall fescue seed lots. Agronomy Abstracts 40, American Society of Agronomy, Madison, Wisonsin.

Dianita, R. (2012). Kajian penggunaan unsur $N$ dan P pada tanaman legum pakan dan non legum untuk sistem integrasi. (PhD), IPB University, Bogor, Indonesia. (in Indonesian language)

Doni, F., Anizan, I., Che Radziah, C. M. Z., Salman, A. H., Rodzihan, M. H. \& Yusof, W. M. W. (2014). Enhancement of rice seed germination and vigour by Trichoderma spp. Research Journal of Applied Sciences, Engineering and Technology, 7(21), 4547-4552.

Gairola, K. C., Nautiyal, A. R. \& Dwivedi, A. K. (2011). Effect of temperatures and germination media on seed germination of Jatropha curcas Linn. Advances In Bioresearch, 2(2): 66-71.

Gashi, B., Abdullai, K., Mata, V. \& Kongjika, E. (2012). Effect of gibberellic acid and potassium nitrate on seed germination of the resurrection plants Ramonda serbica and Ramonda nathaliae. African Journal of Biotechnology, 11(20), 4537-4542.

Ghadir, M., Khah, E. M., Jalali Honarmand, S., Shirkhani, A. \& Shabani, G. (2012). Effects of seed hardness breaking techniques on okra (Abelmoschus esculentus L.) germination. International Journal of Agriculture and Crop Sciences, 4(6), 264-273.

Gunes, E., Gubbuk, H., Silva, T. A., Gozlekci, S. \& Ercisli, S. (2013). Effects of various treatments on seed germination and growth of carob (Ceratonia siliqua L.) Pakistan Journal of Botany, 45(4), 1173-1177.

Guppy, H. B. (1912). Studies in Seeds and Fruits. London, UK: Williams and Norgate. 528 p

Gupta, P. C. (1993). Seed Vigour Testing. In: P. K. Agrawal (Ed.), Handbook of Seed Testing (pp. 242-249). New Delhi, India: DAC, Ministry of Agriculture.

Harrington, G. T. (1916). Agricultural value of hard seeds. Journal of Agricultural Researc, 6, 761795. 
Hassen, A., Pieterse, P. P. \& Rethman, N. F. G. (2004). Effect of pre-planting seed treatment on dormancy breaking and germination of Indigofera accessions. Tropical Grasslands, 38, 154157.

He, Y., Guo, X., Lu, R., Niu, B., Pasapula, V. \& Hou, P. (2009). Changes in morphology and biochemical indices in browning callus derived from jatropha curcas hypocotyls. Plant Cell, Tissue and Organ Culture, 98, 11-17.

Herdiawan, I. \& Sutedi, E. (2012). Produktivitas tanaman pakan Indigofera sp. pada tingkat cekaman kekeringan dan interval pemangkasan berbeda. Jurnal Ilmu Ternak dan Veteriner, 17(2), 161167. (in Indonesian language)

ISTA. (1966). International Rules for Seed Testing. Proceedings for International Seed Testing Association, 31, 1-152

ISTA. (2003). International Rules for Seed Testing. International Seed Testing Association, Zurich.

ISTA. (2007). International Rules for Seed Testing. International Seed Testing Association, Bassersdorf, Switzerland.

Karaguzel, O., Cakmakci, S., Ortacesme, V. \& Aydinoglu, B. (2004). Influence of seed coat treatments on germination and early seedling growth of Lupinus varius L. Pakistan Journal of Botan, 36(1), 65-74

Kefeli, V. I., Kalevitch, M. V. \& Borsari, B. (2003). Phenolic cycle in plants and north et al. 645 environment. Journal of Molecular Cell Biology, 2, 13-18.

Mabhaudhi, T. (2009). Responses of maize (Zea mays L.) landraces to water stress compared with commercial hybrids (176 p). (Master), University of Kwazulu, South Africa.

Maguire, J. D. (1962). Speed of germination-aid in selection and evaluation for seedling emergence and vigor. Crop Science, 2, 176-177.

Marschner, H. (1995). Mineral Nutration of Higher Plants (2nd Ed.). San Diego, California, USA: Academic Press,

McDonnell, A., Grant, M. \& Coons, J. (2012). Effects of hot water on breaking seed dormancy of the endangered kankakee mallow, Iliamna remota Greene (Malvaceae). Erigenia Number, (25), 813.

McIvor, J. G. \& Gardener, C. J. (1987). Effect of boiling water treatment on hard seededness and germination in some Stylosanthes species. Australian Journal of Experimental Agriculture, 27(6), 857-862.

Missanjo, E., Maya, C., Kapira, D., Banda, H. \& Thole, G. K. (2013). Effect of seed size and pretreatment method on germination of Albizia lebbeck. International Scholarly Research Notices. https://www.hindawi.com/ journals /isrn/ 2013/969026/. Accessed on 28 February 2018.

Okunlola, A. I., Adebayo, R. A. \& Orimogunje, A. D. (2011). Methods of breaking seed dormancy on germination and early seedling growth of African locust bean (Parkia biglobosa) (JACQ.) Benth. Journal of Horticulture and Forestry, 3(1), 1-6.

Olatunji, D., Maku, O. J. \& Odumefun, O. P. (2013). The effect of pre-treatment on germination and early seedling growth of Acacia auriculiformis Cunn Ex. Benth. African Journal of Plant Science, 7(8), 325-330.

Palupi, R. (2015). Substitusi protein bungkil kedelai dengan protein tepung pucuk indigofera zollingeriana untuk menghasilkan telur fungsional tinggi antioksidan. (PhD), IPB University, Indonesia, Bogor, Indonesia. (in Indonesian language)

Roberts, E. H. (1973). Predicting the storagelife of seed. Seed Science and Technology, 1, 499-514.

Rusdy, M. (2015). Enhancing germination in seeds of Centrosema pubescens. International Journal of Scientific and Research Publications, 5(10), 1-4.

Santos, C. (2010). Estatística descritiva: Manual de auto aprendizagem (264p). Lisboa, Sílabo.

Sarihan, E. O., Ipek, A., Khawar, K. M., Atak, M. \& Grubuz, M. (2005). Role of $\mathrm{GA}_{3}$ and $\mathrm{KNO}_{3}$ in improving the frequency of seed germination in Plantago lanceolata L. Pakistan Journal of Botany, 37(4), 883-887.

Schmidt, W. C. (1961). Effects of some treatments on the dormancy of western larch seed. (70 p). (Master), Montana State University, USA. 
Schmidth, L. (2002). Pedoman Penanganan Benih Tanaman Hutan Tropis dan Subtropis. Jakarta: Direktorat Jendral Rehabilitasi Lahan dan Perhutanan Sosial Departemen Kehutanan. [in Indonsesian languange]

Shaban, M. (2013). Study on some aspects of seed viability and vigor. International journal of Advanced Biological and Biomedical Research, 1(12), 1692-1697.

Smykal, P., Vernoud, V., Blair, M. W., Soukup, A. \& Thompson, R. D. (2014). The role of the testa during development and in establishment of dormancy of the legume seed. Frontiers in Plant Science, 5(351), 1-19.

Steel, R. G. \& Torrie, J. H. (1980). Principles and Procedures of Statistics a Biometrical Approach (633 p) (2nd Ed.). New York, USA: McGraw-Hill.

Taheri, M. N., Gholami, M., Baninasab, B., Mobli, M. \& Moradi, S. (2014). Pomegranate seed germination and dormancy breaking techniques. Seed Technology, 36(2), 139-149.

Uzan, F. \& Aydin, I. (2004). Improving germination rate of Medicago and Trifolium species. Asian Journal of Plant Science, 3(6), 714-717.

Wycherley, P. R. (1960). Seed germination of some tropical legumes. Journal of Rubber Research Institue of Malaya, 16(2), 99-106.

Yildiztugay, E. \& Kucukoduk, M. (2012). Dormancy breaking and germination requirements for seeds of Sphaerophysa kotschyana Boiss. Journal of Global Biosciences, 1, 20-27.

Yucel, E. (2000). Effects of different salt $(\mathrm{NaCl})$, nitrate $\left(\mathrm{KNO}_{3}\right)$ and sulphuric acid $\left(\mathrm{H}_{2} \mathrm{SO}_{4}\right)$ concentrations on the germination of some salvia species seeds. Seed Science and Technology, 28, 853-860. 